\title{
Using Zinc Oxide Nanoparticles to Improve the Color and Berry Quality of Table Grapes Cv. Crimson Seedless
}

\author{
Mohamed K. Abou El-Nasr ${ }^{1}$ (1), Hussein M. El-Hennawy ${ }^{1}$, Mina S. F. Samaan ${ }^{1}$, Taher A. Salaheldin ${ }^{2}$, \\ Ahmed Abou El-Yazied ${ }^{1}$ (D) and Ashraf El-Kereamy ${ }^{3, *}$ \\ 1 Department of Horticulture, Faculty of Agriculture, Ain Shams University, Cairo 11566, Egypt; \\ Mohamed_aboelnasr@agr.asu.edu.eg (M.K.A.E.-N.); T1salah@yahoo.com (H.M.E.-H.); \\ minasamaan@agr.asu.edu.eg (M.S.F.S.); ahmed_abdelhafez2@agr.asu.edu.eg (A.A.E.-Y.) \\ 2 Pharmaceutical Research Institute, Albany College of Pharmacy and Health Sciences, Albany, NY 12144, USA; \\ taher.salaheldin@acphs.edu \\ 3 Department of Botany and Plant Science, University of California Riverside, Riverside, CA 92507, USA \\ * Correspondence: ashrafe@ucr.edu
}

check for

updates

Citation: Abou El-Nasr, M.K.; El-Hennawy, H.M.; Samaan, M.S.F.; Salaheldin, T.A.; Abou El-Yazied, A.; El-Kereamy, A. Using Zinc Oxide Nanoparticles to Improve the Color and Berry Quality of Table Grapes Cv. Crimson Seedless. Plants 2021, 10, 1285. https://doi.org/10.3390/ plants10071285

Academic Editor: Arnon Dag

Received: 5 June 2021

Accepted: 21 June 2021

Published: 24 June 2021

Publisher's Note: MDPI stays neutral with regard to jurisdictional claims in published maps and institutional affiliations.

Copyright: (c) 2021 by the authors. Licensee MDPI, Basel, Switzerland. This article is an open access article distributed under the terms and conditions of the Creative Commons Attribution (CC BY) license (https:/ / creativecommons.org/licenses/by/ $4.0 /)$.

\begin{abstract}
Producing high-quality table grapes is becoming a challenge in the warmer area of the world due to the global increase in temperature, which negatively affects anthocyanin biosynthesis and other fruit quality attributes. Nanotechnology is a growing field that can be a very useful tool to improve crop productivity and sustainability. The red color is one of the major fruit quality parameters that determine table grape marketability. This study aimed to investigate the role of the zinc element in improving the marketable characteristics of Crimson seedless (Vitis vinifera L.) table grape berries i.e., color, firmness, total soluble solids and sugars; besides its role in activating PAL and SOD enzymatic systems. Additionally, this paper investigated the additive advantages of zinc when applied in nanometric form. Five concentrations of zinc oxide nanoparticles, ZnO NPs (0, 25, 50,100 and $250 \mathrm{ppm}$ ), were compared to zinc oxide in mineral form at a concentration of $250 \mathrm{ppm}$ to investigate their effects on the marketable characteristics of Crimson seedless grape cultivar. The treatments were applied as foliar spray on three-year-old Crimson seedless vines grafted on Richter 110 rootstock grown in one of the major table grape production area in Egypt. The experiment was arranged in completely randomized block design and each vine was sprayed with five letters of the solution. The use of the lowest concentration (25 ppm) of ZnO NPs achieved the highest significant enzyme activity (PAL and SOD). Moreover, the T.S.S, sugars and anthocyanin content in berries increased significantly in association of decreasing acidity. On the other hand, the use of a $50 \mathrm{ppm}$ concentration led to an increase in fruit firmness. Collectively, our data showed that $25 \mathrm{ppm}$ of zinc nanoparticles improved PAL and SOD enzymes activity, improved red coloration in table grape and was more effective than the 250 ppm zinc oxide mineral form.
\end{abstract}

Keywords: Crimson seedless; grape; NPs; ZnO; enzymatic; PAL; SOD; anthocyanin

\section{Introduction}

Crimson seedless (Vitis vinifera L.) grape cultivar is a late red cultivar and has excellent fruit qualities, good natural flavor, as well as strong and crispy berries [1]. However, under some warmer area, such as in Egypt, the cultivar shows a problem in inadequate coloring development of berries, which is one of the main fruit quality parameters [2] and a key factor in determining fruit marketability [3]. It is observed that $30 \%$ or more of the fruit produced by this cultivar may remain on the vine due to insufficient color development [4].

Anthocyanin pigment is responsible for Crimson seedless table grape berry coloration. This pigment is negatively affected by climate and differences between day and night temperature during the veraison stage [5] and it is also affected by the low altitude [6,7]. Various reasons for inferior color development in table grapes have been reported for the conditions prevalent in Egypt, such as high temperature $[8,9]$ ) and vigorous growth with 
dense, shaded canopies $[10,11]$. The dynamics of anthocyanins and enzyme phenylalanine ammonia-lyase (PAL) activity suggested that PAL is an essential enzyme for their biosynthesis [12].

Many attempts were carried out to solve the inadequate grape coloration; application of the ethylene-releasing compound, 2-chloroethylphosphonic acid (2-CEPA), can hasten the accumulation of anthocyanins in grape skin [13]. Nearly all Crimson Seedless vineyards in California require Ethrel (ethephon) for optimum color development, even though it reduces berry firmness compared to untreated fruit [4]. Additionally, it was reported that abscisic acid (ABA) could increase the anthocyanin content in grape skin and might greatly enhance the color property of grapes [14]. In the same trend, it was noted that there was an increase in the anthocyanin content in Crimson seedless berries following the application with the Gibberellic acid inhibitor, Paclobutrazol [15]. Other phytohormones have been used successfully for this purpose, namely Jasmonic acid [16], salicylic acid [17], 1-naphthaleneacetic acid (1-NAA) [18] and 2,4-dichlorophenoxyacetic acid (2,4-D) [19].

Besides phytohormones, there are other endogenous and exogenous factors that regulate the anthocyanin biosynthesis in grapes. Although sugars are mainly accumulated in the pulp, the total sugar content in berry skin also increases during grape ripening. It has been reported that anthocyanins usually accumulate one week after the massive increase in sugar content, which means the sugars in the skins are closely related to anthocyanin biosynthesis [20]. Micronutrients such as zinc (Zn) had an effective role on grapes. Song et al. (2015 a) [21] stated that $\mathrm{Zn}$ treatments enhanced the accumulation of total soluble solids, total phenols, flavonoids, flavanols, tannins and anthocyanins in berry skin, decreasing the concentration of titratable acidity.

Nanotechnology has been recognized as an efficient enhancement in the agricultural field because of its unique physicochemical properties; nanomaterials are increasingly used in agriculture to enhance the biomass of plants because of its small size with a large surface area [22,23]. However, this technique has only recently been used for fruit crops as most studies, such as those reported by [24,25], were conducted on field crops and some vegetable crops. In this regard, foliar spraying of micro-nutrients in nano-form is more suitable than the soil application due to the ease of application, reducing toxicity resulting from the accumulation of micro-nutrients and avoiding fixation in the soil [26].

Zinc Oxide Nanoparticles (ZnO NPs) are nano scaled micro-nutrients which were used in low concentrations and play an important role in plant functions. ZnO NPs enhance the growth characteristics of many plants, including Peanuts [27], Pearl millet [28], Cotton [29], Purslanes [30] and Coffee [31]. ZnO NPs modify the effect of auxin by regulating the tryptophan synthesis and influencing fruit quality [32,33]. Additionally, they act as a co-factor to many enzymes' activity such as superoxide dismutase (SOD), glutathione peroxidase (GPX) [34,35] and phenylalanine ammonia-lyase (PAL) [36,37].

The goal of this work was to evaluate the influence of $\mathrm{ZnO} N P s$ as foliar spray on enzymatic activity and marketable characteristics including color, TSS, sugars and firmness of Crimson seedless table grape.

\section{Results}

\subsection{Characterization of Zinc Oxide Nanoparticles ( $\mathrm{ZnO} N P_{s}$ )}

Zinc oxide nanoparticles were synthesized by co-precipitation method at alkaline $\mathrm{pH}$ using urea as a stabilizing and reducing agent as previously described. Dynamic light scattering (DLS) showed the average particle size to be $97.31 \mathrm{~nm}$ and zeta potential of $-2.27 \mathrm{mV}$ as measured by the electrophoretic light-scattering technique, Figure 1A,B.

The topographical SEM image showed well-formed spherically shaped $100 \mathrm{~nm}$ particles, see Figure 2A, that were in accordance with the DLS measurements. XRD patterns were compared to the standard pattern of $\mathrm{ZnO}$ (card \#: 01-079-0206), which showed that the diffraction peaks at $2 \theta=31.7,34.4,36.2,47.5,65.5,62.9,66.3,68$ and 69.1 corresponded to $\mathrm{hkl}=100,002,101,102,110,103,200,112$ and 201, respectively which were quite identical to the characteristic peaks of the $\mathrm{ZnO}$ crystal, as shown in Figure 2B. 
A

$\begin{array}{rllll} & & \text { Size (d.nm): } & \text { \% Intensity: } & \text { St Dev (d.nm): } \\ \text { Z-Average (d.nm): } 79.38 & \text { Peak 1: } & 97.33 & 100.0 & 41.50 \\ \text { Pdl: } 0.178 & \text { Peak 2: } & 0.000 & 0.0 & 0.000 \\ \text { Intercept: } 0.934 & \text { Peak 3: } & 0.000 & 0.0 & 0.000\end{array}$

Result quality : Good

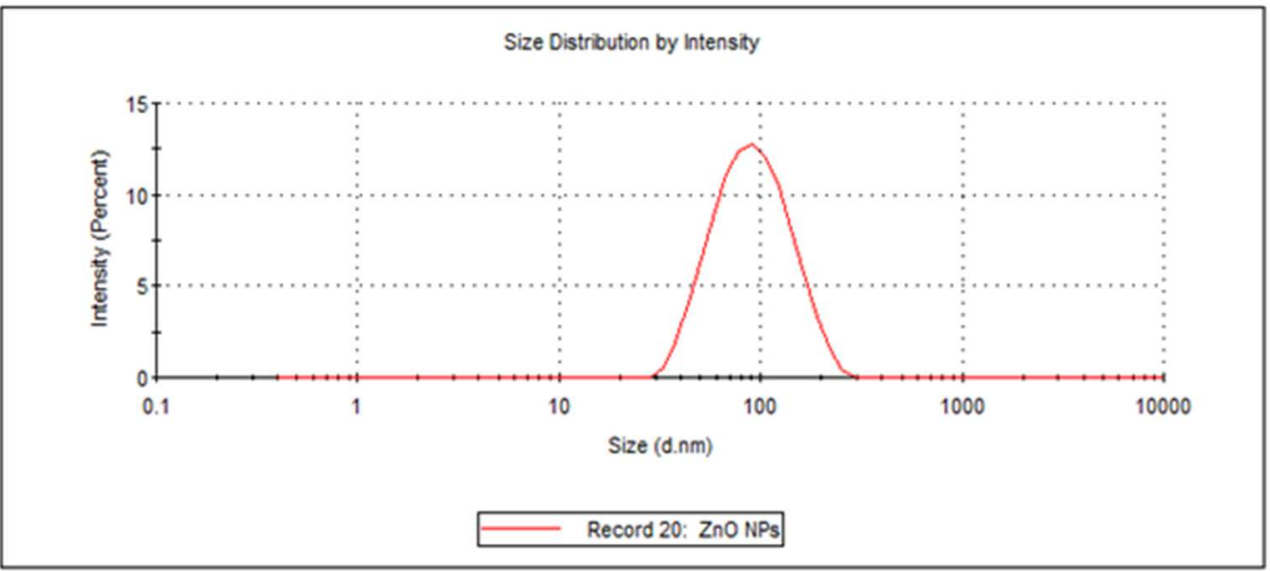

B

\begin{tabular}{|c|c|c|c|c|}
\hline & & Mean (mV) & Area $(\%)$ & St Dev (mV) \\
\hline Zeta Potential (mV): -2.27 & Peak 1: & -2.27 & 100.0 & 1.14 \\
\hline Zeta Deviation (mV): 1.14 & Peak 2: & 0.00 & 0.0 & 0.00 \\
\hline Conductivity $(\mathrm{mS} / \mathrm{cm}): 0.0702$ & Peak 3: & 0.00 & 0.0 & 0.00 \\
\hline
\end{tabular}

Result quality : Good

Zeta Potential Distribution

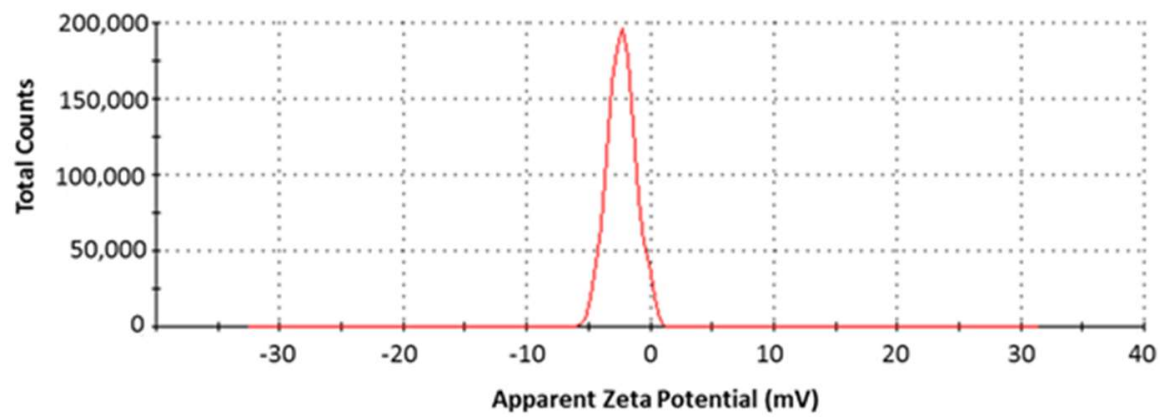

Record 13: ZnO NPs

Figure 1. Physicochemical characterization of $\mathrm{ZnO}$ nanoparticles. (A): particle size distribution measured by DLS. (B): Zeta potential measured by ELS.

\subsection{Physiochemical Fruit Properties Evaluation}

Data in Table 1 demonstrated that foliar spraying of ZnO NPs significantly affected the studied parameters of crimson seedless grape cultivar during the two seasons. The highest T.S.S. brix values, 18.1 and 19.5, were obtained when the vines were sprayed with $25 \mathrm{ppm}$ of $\mathrm{ZnO}$ NPs in both seasons, respectively, while the minimum values of T.S.S., 15 and 15.6, were recorded in berries in the control treatment during the first and second seasons, respectively. Concerning the fruit acidity percentage, the highest percentages 
were obtained in the berries of untreated vines (control), 0.672 and 0.657 , in both seasons, respectively. The lowest acidity percentages, 0.598 and 0.591 , were found in the berries of the vines treated with $\mathrm{ZnO}$ NPs at $50 \mathrm{ppm}$ in the first and second seasons, respectively. As for the T.S.S./acid ratio, the results revealed that spraying with ZnO NPs at $50 \mathrm{ppm}$ achieved the highest significant percentage, 30.00, in the first season, whereas the second season data favored $25 \mathrm{ppm} \mathrm{ZnO}$ NP-treated vines, 32.00. The lowest values (22.7 and 23.8) were found in control vines in the first and second seasons, respectively. Regarding the berries' firmness, the firmest berries were found in the vines treated with $250 \mathrm{ppm} \mathrm{ZnO}$ NPs in the first season $(165.6 \mathrm{~g} / \mathrm{mm})$; the difference was insignificant when compared to the other treated vines. In the second season, the same treatment produced the firmest berries $(264.3 \mathrm{~g} / \mathrm{mm})$; the difference was significant compared to the other treated vines, except those of $100 \mathrm{ppm}$ treatment. On the other hand, control vines in both seasons had lower values of berry firmness, 130.6 and $207.9 \mathrm{~g} / \mathrm{mm}$, and produced a significant amount of the softest berries.


Figure 2. Characterization of $\mathrm{ZnO}$ nanoparticles. (A): SEM image shows spherical nanoscale (80-130 nm) particles. (B): XRD pattern showing the c phase patten of $\mathrm{ZnO}$ crystal.

Table 1. Effect of foliar spraying of ZnO NPs on some physiochemical fruit properties of Crimson seedless grape cultivar during two seasons (2019 and 2020).

\begin{tabular}{|c|c|c|c|c|c|c|c|c|}
\hline Character (Means) & $\begin{array}{l}\text { T.S.S } \\
\text { (Brix) }\end{array}$ & Acidity \% & T.S.S/Acid Ratio & $\begin{array}{c}\text { Firmness } \\
(\mathrm{g} / \mathrm{mm})\end{array}$ & $\begin{array}{l}\text { T.S.S } \\
\text { (Brix) }\end{array}$ & Acidity \% & T.S.S/Acid Ratio & $\begin{array}{c}\text { Firmness } \\
(\mathrm{g} / \mathrm{mm})\end{array}$ \\
\hline Treatments & \multicolumn{4}{|c|}{ First season (2019) } & \multicolumn{4}{|c|}{ Second season (2020) } \\
\hline 0 ppm (Control) & $15.0^{\mathrm{c}}$ & $0.672^{\mathrm{a}}$ & $22.4^{\mathrm{c}}$ & $130.6^{\mathrm{b}}$ & $15.6^{\mathrm{b}}$ & $0.657^{\mathrm{a}}$ & $23.7^{b}$ & $207.9^{d}$ \\
\hline 25 ppm ZnO NPs & $18.1^{\mathrm{a}}$ & $0.616^{\mathrm{ab}}$ & $29.5^{\mathrm{a}}$ & $152.8^{\mathrm{a}}$ & $19.5^{\mathrm{a}}$ & $0.613^{\mathrm{ab}}$ & $32.0^{\mathrm{a}}$ & $240.0^{b c}$ \\
\hline 50 ppm ZnO NPs & $17.7^{\mathrm{a}}$ & $0.598^{b}$ & $29.7^{a}$ & $156.9^{\mathrm{a}}$ & $18.6^{\mathrm{a}}$ & $0.591^{b}$ & $31.7^{\mathrm{a}}$ & $236.0^{b c}$ \\
\hline 100 ppm ZnO NPs & $17.2^{\mathrm{a}}$ & $0.666^{\mathrm{a}}$ & $25.9^{b}$ & $160.1^{a}$ & $18.6^{\mathrm{a}}$ & $0.627^{\mathrm{ab}}$ & $29.9^{a}$ & $261.1^{\mathrm{ab}}$ \\
\hline 250 ppm ZnO NPs & $17.5^{\mathrm{a}}$ & $0.628^{a b}$ & $27.9^{a b}$ & $165.6^{\mathrm{a}}$ & $19.3^{\mathrm{a}}$ & $0.626^{\mathrm{ab}}$ & $30.9^{a}$ & $264.3^{a}$ \\
\hline $250 \mathrm{ppm} \mathrm{ZnO}$ & $16.3^{b}$ & $0.616^{\mathrm{ab}}$ & $25.8^{\mathrm{b}}$ & $154.7^{\mathrm{a}}$ & $16.5^{\mathrm{b}}$ & $0.648^{a}$ & $25.7^{\mathrm{b}}$ & $218.6^{\mathrm{cd}}$ \\
\hline
\end{tabular}

Means in each column with the same letter(s) are not significantly different at $5 \%$ level. Different letters indicate the differences based on Duncan's multiple range test. 


\subsection{Chemical Fruit Characteristics}

\subsubsection{Total Anthocyanin}

$\mathrm{ZnO}$ nanoparticles showed a significant $(p<0.05)$ increase in the anthocyanin content of berries skin in treated vines compared to control vines, as shown in Figure 3. When the vines were treated with $25 \mathrm{ppm}$ of $\mathrm{ZnO} \mathrm{NPs}$, anthocyanin content in their berries increased by $150 \%$ and $328 \%$ compared to the control vines in the first and second seasons, respectively. Figure 4 demonstrates the color differences among the clusters of the treated vines.

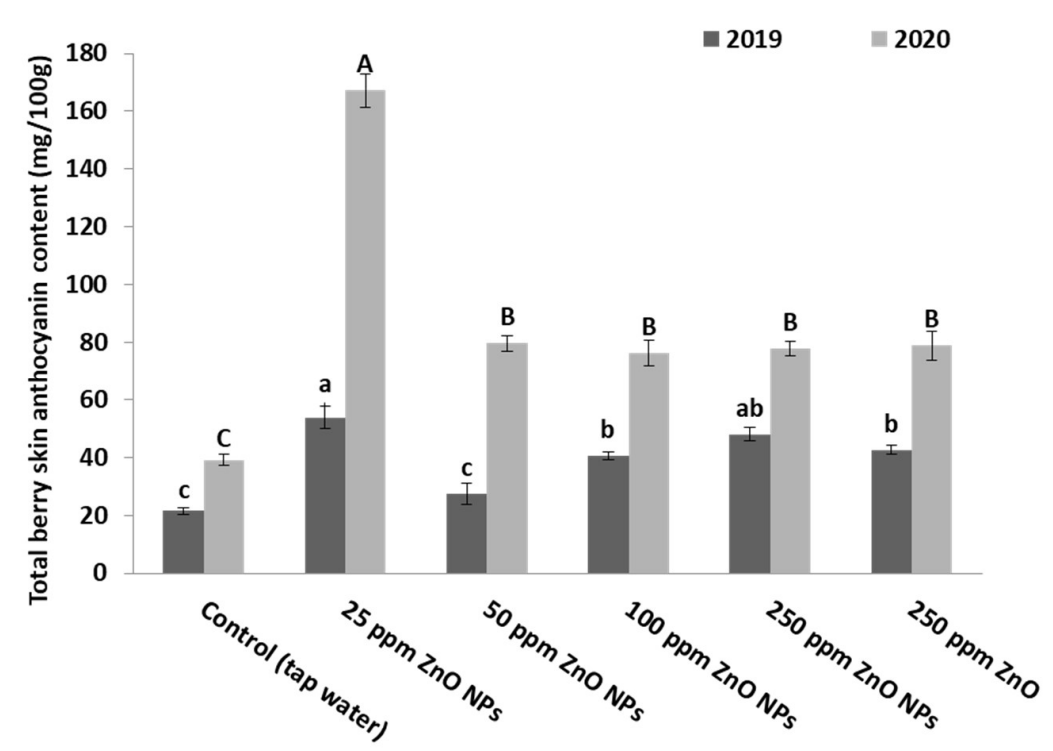

Figure 3. Effect of foliar spraying of ZnO NPs on the total anthocyanin content in the berry skin of Crimson seedless grape cultivar during two seasons: 2019 and 2020. Different letters indicate the differences based on Duncan's multiple range test.

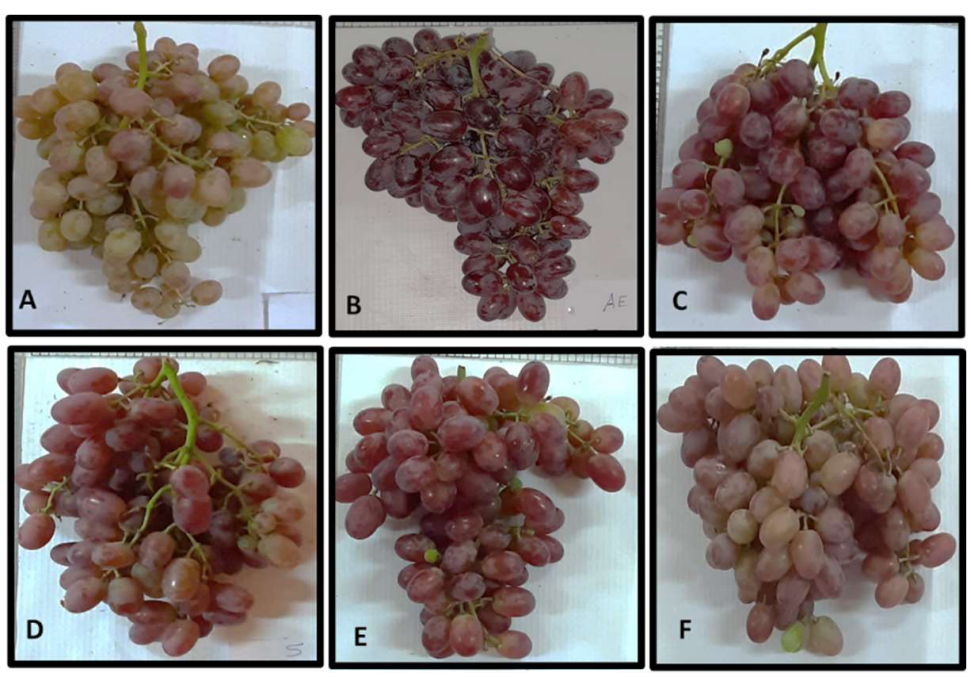

Figure 4. Effect of foliar spraying with $\mathrm{ZnO}$ NPs on coloring of Crimson seedless grape clusters. (A): water-treated clusters as a control, (B-E): 25, 50, 100 and 250 ppm ZnO NPs, (F): 250 ppm ZnO.

\subsubsection{Total and Reducing Sugars}

It is evident that there is an increase in the total and reducing sugar content in berries due to the foliar application of all $\mathrm{ZnO}$ nanoparticles concentrations compared to control (Figure 5A,B). The berries of the vines treated with ZnO NPs at $25 \mathrm{ppm}$ achieved the maximum increase in total sugars (8.10 and 7.05) and reducing sugars (3.69 and 3.68) content in both seasons, respectively, compared to $\mathrm{ZnO}$ and control treatments. 


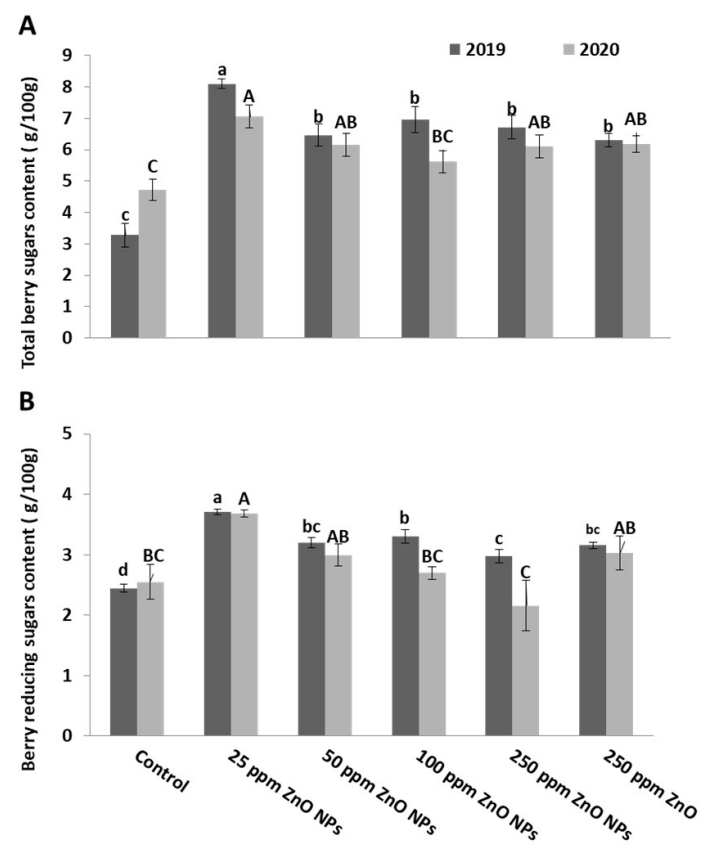

Figure 5. Effect of ZnO NPs foliar spraying on leaf enzymatic activity, (A) PAL and (B) SOD, of grapevine Crimson seedless cultivar during two seasons: 2019 and 2020. Different letters indicate the differences based on Duncan's multiple range test.

\subsection{Enzyme Activity}

The level of antioxidant enzymes in mature leaves of the crimson seedless grape cultivar increased by ZnO NPs application in two seasons. An increase in PAL enzyme activity was observed in $\mathrm{ZnO} N \mathrm{~N}$-treated vines. Similar to previous parameters, the highest activity was observed at $25 \mathrm{ppm}$ ZnO NPs (Figure 6A). Likewise, SOD enzyme activity increased at $25 \mathrm{ppm}$ ZnO NPs (Figure 6B).
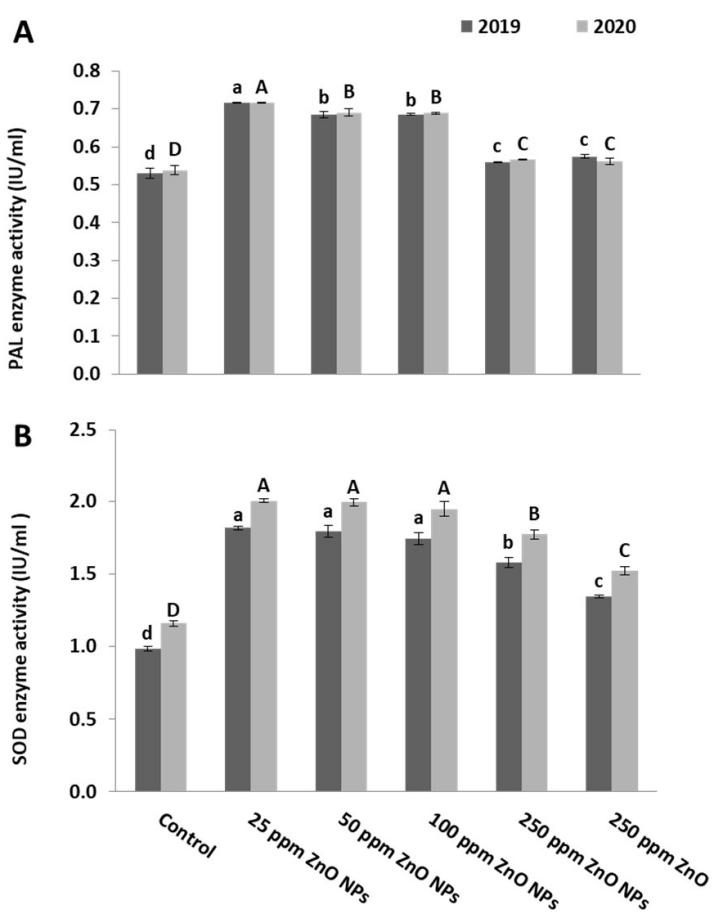

Figure 6. Effect of ZnO NPs foliar spraying on total sugar (A) and reducing sugar (B) (g/100 g) in berries of Crimson seedless grape cultivar during two seasons: 2019 and 2020. Different letters indicate the differences based on Duncan's multiple range test. 


\section{Discussion}

As an essential microelement, zinc (Zn) plays a critical role in several plant growth and development functions. Consequently, it significantly affects the growth and quality of agricultural crops. Many studies have showed that the application of $\mathrm{Zn}$ can improve the quality of many vegetables and fruits [38-41]. Nanotechnology provides certain advantages when applying the $\mathrm{Zn}$ micronutrient in nanometric form, thanks to its large surface area and intensive surface charge and high resonance of its particles, which includes high absorption efficiency as well as speed uptake and movement inside the plant's vascular tissues. Data obtained from the current study are in line with these suggestions; no significant difference was observed in the leaves' Zn content in the 25 ppm ZnO NPs and 250 ppm ZnO during the first year of the study (Figure S2). In the second year, a significant difference was observed in the leaves' Zn content in the 100 ppm ZnO NPs and 250 ppm ZnO during the second year of the study (Figure S2). Our study investigated the impacts of zinc nanoparticles on fruit quality of Crimson seedless table grape as an important and desired cultivar in Egypt. Zn nanoparticles clearly affected berry firmness, T.S.S., titratable acidity, sugars, anthocyanin content and enzyme activity of PAL and SOD systems.

Our study showed that ZnO NPs foliar spraying enhanced T.S.S., diminished acidity and increased the firmness of Crimson seedless grape cultivar. These effects could be due to the role of $\mathrm{Zn}$ in the transference and synthesis of proteins and carbohydrates, as well as the maintenance of the structural stability of cell membranes [33]. Additionally, zinc plays an important role in many biochemical pathways [42]. In this concern, our results were parallel with those of Song et al. [21], who stated that $\mathrm{Zn}$ treatments enhanced the accumulation of total soluble solids, total phenols, flavonoids, flavanols, tannins and anthocyanins in berry skin while decreasing the concentration of titratable acidity. Simultaneously, our results also agreed with those of Davarpanah et al. [43], who elucidated that foliar spraying with $\mathrm{ZnO}$ NPs led to significant increases in quality of pomegranate fruits, including increases in T.S.S. and decreases in titratable acidity. Additionally, our findings also resembled those of Usha and Singh [44] and Abou-Zaid and Shaaban [45], who reported that zinc improved the total soluble solids and reduced the total acidity of grapes.

$\mathrm{ZnO} N \mathrm{NP}$ application enhances the activity of antioxidant enzymes [46]. In our experiment, ZnO NPs at 25 ppm increased the SOD activity in leaves; the reason of the increase may be due to the role of zinc as a structural and catalytic component to enzymes required for growth and development of plants [47,48]. Moreover, $\mathrm{Zn}$ controls the generation and detoxification of free oxygen radicals, which may damage lipids of the membrane and may help to reduce lipid peroxidation rate, since it is a stabilizing and protective component of bio membranes against activated oxygen species [34]. The present observation is supported by the previous work of Kouhi et al. [49], who reported that ZnO NPs in the lowest concentration also enhanced the antioxidant capacity in grapeseed.

The PAL enzyme gives cinnamic acids through the disposal of ammonia from phenylalanine. Cinnamic acids are relatively simple secondary metabolites derived from the shikimic acid pathway in some plants [50]. Foliar spraying of ZnO NPs in our study increased PAL activity in Crimson grape leaves. Our results agreed with the findings of Wadhwa et al. [51], who revealed that Zn acts as a co-factor for PAL enzyme activity. Additionally, Karimzadeh et al. [36] found that the highest activity of the PAL enzyme was found when using $30 \mathrm{ppm}$ nano-ZnO in flax plant.

Anthocyanin synthesis is greatly influenced by temperature. In fact, data presented in Figure S1 showed high maximum temperature peaks in both seasons (2019 and 2020) at veraison stage until harvest. The maximum daily temperature reached $45^{\circ} \mathrm{C}$, which occurred especially frequently in the 2019 season. The minimum temperature (night temperature) was below $20^{\circ} \mathrm{C}$ on most nights, which may be favorable for anthocyanin accumulation in the 2020 season compared to the 2019 season, which had night temperatures above $20^{\circ} \mathrm{C}$ on most days at the same stage of development, as shown in Figure S1. These interpretations were compatible with what was advocated by Mori et al. [52], who mentioned that a moderate temperature, such as $25^{\circ} \mathrm{C}$, favored anthocyanin biosynthesis, whereas a high 
temperature, such as $35^{\circ} \mathrm{C}$, is associated with anthocyanin degradation and inhibition of anthocyanin accumulation. Additionally, high night temperature inhibits the gene expression of the anthocyanin biosynthesis genes, CHS, F3H, DFR, ANS and UFGT, at the early stages of ripening and dramatically reduces the activity of UFGT, resulting in poor production of anthocyanins. It is vital to mention that high temperature during the 2019 season, especially night temperature, might delayed the color-based harvest date due to anthocyanin degradation. Moreover, in the 2020 season, the harvest date was earlier because it was cooler than the 2019 season. These findings agree with those of Mori et al. [52], who stated that the C13-labeled anthocyanins were significantly reduced after high temperature treatment, suggesting that the anthocyanin-level was not only influenced by the lower expression of the structure and regulatory genes, but also by the degradation of the previously synthesized anthocyanins. Furthermore, the macroscopic view of Cohen et al. [53] and Ortega-Regules et al. [54] stated that the lowest concentration of anthocyanins in the berries is usually obtained in the warmest years, whereas in the cooler years the grapes produce more anthocyanins.

Anthocyanin biosynthesis occurs in red berry skins through the flavonoid pathway, which starts with the precursor phenylalanine [55]. Foliar application of ZnO NPs at low concentrations enhanced the anthocyanin content in the berries' skin. Our results were consistent with Song et al. [21], who mentioned that Zn treatments enhanced the accumulation of anthocyanins in berry skin, and Hashemi et al. [56], who explained the role of $\mathrm{ZnO}$ nanoparticles in increasing anthocyanin production in soybean. Additionally, Wadhwa et al. [51] mentioned that Zn served as a co-factor for PAL enzyme activity and Medda et al. [12] advocated that Zn played a regulatory enzyme during fruit ripening for flavonoid biosynthesis.

A change of the total and reducing sugar in berries was observed after ZnO NPs treatment, which increased at low concentrations. Raigond et al. [57] agreed with our findings, as they observed that total soluble sugars increased significantly with 500 ppm $\mathrm{Zn}-\mathrm{NPs}$ treatment in potato plants and reducing sugars in Licorice plants increased with $\mathrm{Zn}-\mathrm{NPs}$ treatment compared to the control plants [58]. The reason for the increasing sugar content in berries may be due to the role of zinc in carbohydrate metabolism by improving the photosynthesis and sugar transformation [59]. Additionally, Song et al. [21] reported that foliage sprayed zinc sulfate showed promoting effects on the photosynthesis and berry development of vines (the promotion of photosynthesis mainly occurred from the veraison stage to maturation).

Nanomaterials, as a new technology in agriculture, may be met by some anxiety toward its prospective effects on human health. There were various studies that handled the effect of Zn NPs on animals. Long et al. [60] reported that feeding experimental animals with a low dose of ZnO NPs had better effects on growth performance and was beneficial to the urinary system wellness. On the other hand, the biochemical markers in the serum of rabbits showed that there was no toxic effect of ZnO NPs on liver or kidney functions, as the concentration of blood biochemical parameters were in the normal range [61]. In the same context, a previous study revealed that zinc has different ways of protecting the liver from cirrhosis [62]. In conclusion, we provided data on the potential use of nanoparticles as an applied tool to improve red coloration and the marketability of table grapes.

\section{Materials and Methods}

\subsection{Preparation and Characterization of Zinc Oxide Nanoparticles ( $\mathrm{ZnO} N \mathrm{NS}_{\mathrm{s}}$ )}

Zinc oxide nanoparticles were synthesized by a co-precipitation method using urea reduction of zinc nitrate hexahydrate at alkaline $\mathrm{pH}[63,64]$. Briefly, $50 \mathrm{~mL}$ of $1 \mathrm{M}$ urea solution was added to $50 \mathrm{~mL}$ of $0.5 \mathrm{M}$ zinc nitrate hexahydrate solution while stirring at $600 \mathrm{rpm}$ at room temperature for $15 \mathrm{~min}$. To this mixture, $10 \mathrm{~mL}$ of $1 \mathrm{M}$ sodium hydroxide solution was added dropwise under continuous stirring at $800 \mathrm{rpm}$ at $70{ }^{\circ} \mathrm{C}$ for $2 \mathrm{~h}$. White suspension of zinc hydroxide $\left(\mathrm{Zn}(\mathrm{OH})_{2}\right)$ nanoparticles then formed. In order to remove unreacted substrates, the suspension was first centrifuged at $40,000 \times g$ for 
$30 \mathrm{~min}$, and the precipitate was then washed three times with deionized water (Milli-Q, Millipore, Burlington, MA, USA). Afterward, the precipitate was annealed at $500{ }^{\circ} \mathrm{C}$ for $3 \mathrm{~h}$ in the muffle furnace (Thermolyne ${ }^{\mathrm{TM}}$, Thermo Fisher Scientific, Waltham, MA, USA) to convert zinc hydroxide into white zinc oxide nanoparticles ready for field application after physicochemical characterization.

Particle size distribution and surface charge (Zeta potential) were measured by dynamic light scattering (DLS) and electrophoretic light scattering (ELS) (ZS nano, MalvernPanAnalytical, Westborough, MA, USA). A total of $10 \mathrm{mg}$ of $\mathrm{ZnO}$ nanoparticles were suspended in $10 \mathrm{~mL}$ of deionized water using an ultrasonic prob at $80 \mu \mathrm{m}$ amplitude (Q55, Qsonica LLC., Newtown, CT, USA). Then, $1 \mathrm{~mL}$ was transferred to a $2 \mathrm{~mL}$ cuvette for size measurement and $1 \mathrm{~mL}$ was injected into a zeta potential cell for particle surface charge measurement. $\mathrm{ZnO}$ nanoparticles surface morphology was examined by scanning electron microscope (ESEM, Quattro S, Thermo Scientific, Waltham, MA, USA) instrument with acceleration voltage of 5-30 kV. Well-dried samples were carefully sectioned, then fixed on specific grids. The crystallographic phase pattern was identified using an X-ray diffractometer (XRD, X'Pert PRO Malvern-PANalytical, Etten Leur, The Netherlands) operated at $45 \mathrm{kV}$ and $30 \mathrm{~mA}$ using filtered $\mathrm{Cu} \mathrm{K} \alpha$ radiation $(\lambda=1.5404 \AA)$ in the $2 \theta$ from $5^{\circ}$ to $80^{\circ}$ and data analysis was performed by high score plus software.

\subsection{Plant Material and Treatments}

This experiment was carried out in El-Ghandour farm, located at Cairo Alex Desert Road K78, Egypt at an altitude of 56 m, in two successive seasons (2019 and 2020). The vines of Crimson seedless grape cultivar grafted on Richter 110 rootstock were three years old, mature and chosen as uniform as possible in terms of growth and vigor. Vines were planted at $2 \times 3 \mathrm{~m}$ apart in sandy soil under drip irrigation system, trellised by Spanish Parron system and trained by the "four arms" system pruned by the Guyot system. All vines were subjected to the same horticultural practices as recommended according to the farm conditions. The daily maximum and minimum temperature records during the two seasons were obtained by the Central Laboratory for Agricultural Climate-the Egyptian Ministry of Agriculture and Land Reclamation for the experimental site "Cairo-Alexandria Desert Road-K78" in Figure S1.

$\mathrm{ZnO} N$ Ps were used at different concentrations $(0,25,50,100$ and $250 \mathrm{ppm})$ compared to the regular $\mathrm{ZnO}$ concentration of $250 \mathrm{ppm}$. The control treatment $(0 \mathrm{ppm})$ consisted of spraying with tap water only. These foliar treatments were applied three times during the season in April, May and June. Each vine received about $5 \mathrm{~L}$ of spraying solution until runoff.

\subsection{Leaf Zn Content Analysis}

Twenty leaves/vine from the middle of tagged shoots were separated, washed with tap water, rinsed with distilled water and dried at $70{ }^{\circ} \mathrm{C}$ until a constant weight and then ground to a powdery texture. Half a gram of dry sample was wet digested with $20 \mathrm{~mL}$ of $95 \% \mathrm{H}_{2} \mathrm{SO} 4$ and $5 \mathrm{~mL}$ of $30 \% \mathrm{H}_{2} \mathrm{O}_{2}$ until the mixture was clear then filtered, transferred quantitatively and filled to a volume of $50 \mathrm{~mL}$ using distilled water [65]. The $\mathrm{Zn}$ content of a leaf was determined by using Absorption Spectroscopy according to [66]. Data are presented in Figure S2.

\subsection{Physiochemical Fruit Properties Evaluation}

The total soluble solids were determined in berry juice by manually squeezing berries in a refractometer (PZO-RR13, Warszawa, Poland) with a scale of 0 to $35 \%$. As for the titratable acidity (TA), fruits were cut into pieces to make homogeneous mixture. Next, a $50 \mathrm{~g}$ sample was taken then processed for $40 \mathrm{~s}$ in a blender. Titratable acidity of the juice was determined manually according to AOAC [67]. Berry firmness was determined by using GÜSS Fruit Texture Analyzer (FTA), the maximum force required was recorded in $\mathrm{g} / \mathrm{mm}$. 


\subsection{Enzyme Activity}

Phenylalanine ammonia-lyase (PAL) enzyme activity (IU/mL enzyme) was calculated by tracking the increase in the absorbance reading at the wavelength of $290 \mathrm{~nm}$ due to the formation of cinnamic acid [68]. In brief, a leaf sample of $1 \mathrm{~g}$ was ground in $4 \mathrm{~mL}$ extraction buffer (the buffer consisted of $1 \mathrm{M}$ phosphate buffer, $\mathrm{pH} 7$, containing $0.1 \mathrm{mM}$ EDTA and $1 \%$ polyvinylpyrrolidone (PVP)). The homogenates were centrifuged under cooling for $15 \mathrm{~min}$. The supernatant was collected and used for the assays of enzymatic activities. The enzyme activity was determined by taking $1 \mathrm{~mL}$ of a borate buffer $(\mathrm{pH} 8.8,0.1 \mathrm{M})$ solution then adding $1 \mathrm{~mL}$ of $12 \mathrm{mM}$ phenylalanine acid. Finally, $0.8 \mathrm{~mL}$ of the enzymatic extract was added.

$$
\text { enzyme activity }(\mathrm{IU} / \mathrm{mL})=((\Delta \mathrm{A} / \mathrm{min}) / \varepsilon) \times(\text { test volume } / 1000) \times 106 \times(1 / 0.8)
$$

where $\Delta \mathrm{A}$ is the difference between reading absorbance, $\varepsilon$ is the extinction coefficient $=9630 \mathrm{~L} \mathrm{~mol}^{-1} \mathrm{~cm}^{-1}$ and the test volume $=2.8 \mathrm{~mL}$.

Superoxide dismutase (SOD) enzyme activity (IU/mL enzyme) was calculated according to the method of Beyer and Fridovich [69], in which the amount of enzyme required to inhibit Nitro Blue Tetrazolium 'NBT' is expressed at $50 \%$. In brief, the $1 \mathrm{~g}$ leaf sample was ground in $4 \mathrm{~mL}$ extraction buffer (the buffer was prepared using $0.05 \mathrm{M}$ phosphate buffer, $\mathrm{pH} 7.8$, containing $0.1 \mathrm{mM}$ EDTA and $1 \%$ polyvinylpyrrolidone (PVP)). The homogenates were centrifuged under cooling for $15 \mathrm{~min}$. The supernatant was collected and used for the assays of enzymatic activities. The reaction was mad by taking $0.1 \mathrm{~mL}$ of the enzymatic extract and adding it to $3 \mathrm{~mL}$ of the reaction mixture $(0.05 \mathrm{M} \mathrm{L}$-methionine, $1 \mathrm{mM} \mathrm{NBT}$, $0.01 \mathrm{M}$ EDTA, $50 \mathrm{mM}$ phosphate buffer (pH 7.8), 0.2 M Riboflavin), after which the tubes were placed under two $15 \mathrm{~W}$ fluorescent lamps for 20 minutes to start the reaction. The blank tubes were kept in the dark. The absorbance was recorded at $560 \mathrm{~nm}$.

$$
\begin{aligned}
& \% \text { of inhibition }=((\text { A control }- \text { A sample }) / A \text { control }) \times 100 \\
& \text { enzyme activity }(\mathrm{IU} / \mathrm{mL})=(\% \text { of inhibition } / 50) \times(1 / 0.1)
\end{aligned}
$$

where $\mathrm{A}$ is the absorbance reading.

\subsection{Fruit Bio-Chemical Components 4.6.1. Total Anthocyanin}

The total anthocyanin content was determined according to the method of Connor et al. and Lima et al. [70,71] Briefly, one gram of fresh berries skin was soaked for $24 \mathrm{~h}$ in acidic alcohol $(1 \mathrm{M} \mathrm{HCl} /$ methanol as 15:85 $\mathrm{v} / \mathrm{v})$ to extract the pigment. The samples were then measured using a spectrophotometer at a wavelength of $530 \mathrm{~nm}$. The values were expressed as milligrams cyanidin-3-glucoside (c3g) equivalents per $100 \mathrm{~g}$ fresh weight. All determinations were performed in triplicates.

\subsubsection{Total and Reducing Sugars}

Total and reducing sugars were determined by the iodometric titration method according to Shaffer and Hartmann [72]. One gram of fresh leaves received $15 \mathrm{~mL}$ of $95 \%$ ethyl alcohol and placed into a water bath for $3 \mathrm{~h}$ then cooled, filtered and washed by $80 \%$ ethyl alcohol. It was then transferred quantitatively - the tube was filled to a volume of 25 $\mathrm{mL}$ using $80 \%$ ethyl alcohol.

Total sugars: $15 \mathrm{~mL}$ of the filtrated extract was added to $5 \mathrm{~mL}$ of $\mathrm{HCl} 2 \mathrm{M}$; the previous mixture was heated in a water bath $\left(60^{\circ} \mathrm{C}\right)$ for $30 \mathrm{~min}$ and then held until cooled. A drop of methyl red was then added until reaching a light pink color and the beaker was filled up to $50 \mathrm{~mL}$ with distilled water. The total sugars were determined by adding $5 \mathrm{~mL}$ of beaker contents to $5 \mathrm{~mL}$ of Fehling's solution and heating the mixture until boiling vigorously for $15 \mathrm{~min}$ in a water bath. Afterward, it was subjected to running water for $3 \mathrm{~min}$ to cool followed by the addition of $2 \mathrm{~mL}$ of potassium iodate $2 \%$ and $2 \mathrm{~mL}$ of sulfuric 
acid $2 \mathrm{M}$. Titration was done using sodium thiosulfate solution until the solution had a yellowish-green color, after which drops of starch (blue color) were added until no change in color was observed. The number of milligrams of total dissolved sugars $(\mathrm{g} / 100 \mathrm{~g}$ fresh weight) was calculated:

$$
\begin{gathered}
\text { Total sugars }(\mathrm{g} / 100 \mathrm{~g} \text { fresh weight })=(250 / 100) \times(90 / \mathrm{A} \times 35.67) \times(\text { beaker capacity } / 5) \\
\times(\text { B blank }- \text { B sample }) \times(100 / \text { sample weight }) \times(50 / 15)
\end{gathered}
$$

where $\mathrm{A}$ is the thiosulfate molarity and $\mathrm{B}$ is the titration reading.

Reducing sugars: $10 \mathrm{~mL}$ of the filtrated extract was placed in a water bath $\left(60{ }^{\circ} \mathrm{C}\right)$ for $15 \mathrm{~min}$, then transferred quantitatively using hot distilled water to a beaker and three drops of phenol indicator were added. Once the solution was titrated using sodium hydroxide $0.2 \mathrm{M}, 5 \mathrm{~mL}$ of lead acetate was added by dripping. To neutralize the excessive amount of lead acetate, acidic sodium phosphate was added. Finally, the beaker contents were filtered and filled up to $25 \mathrm{~mL}$ using distilled water. The reducing sugars were determined by adding $5 \mathrm{~mL}$ of beaker contents to $5 \mathrm{~mL}$ of Fehling's solution, after which the mixture was heated until boiling vigorously for $15 \mathrm{~min}$ in a water bath. It was then subjected to running water for $3 \mathrm{~min}$ to cool, followed by the addition of $2 \mathrm{~mL}$ of potassium iodate $2 \%$ and $2 \mathrm{~mL}$ of sulfuric acid $2 \mathrm{M}$. Titration was done using a sodium thiosulfate solution until it had a yellowish-green color, after which drops of starch (blue color) were added until the color disappeared. The number of milligrams of total dissolved sugars $(\mathrm{g} / 100 \mathrm{~g}$ fresh weight) was calculated:

$$
\begin{gathered}
\text { Reducing sugars }(\mathrm{g} / 100 \mathrm{~g} \text { fresh weight })=(250 / 100) \times(90 / \mathrm{A} \times 35.67) \times(\text { beaker capacity } / 5) \\
\times(\text { B blank }- \text { B sample }) \times(\text { sample weight } / 100)
\end{gathered}
$$

where $\mathrm{A}$ is the thiosulfate molarity and $\mathrm{B}$ is the titration reading.

\subsection{Statistical Analysis}

The experiment was arranged in complete randomized block design; each treatment was conducted by five replicates. All statistical analysis of the different traits was performed using the SPSS program software (SPSS, 20). Differences among treatments were tested by Duncan's Multiple Range test [73].

\section{Conclusions}

From the previously explored results, we can conclude that Crimson seedless grapevines treated with ZnO NPs at a concentration of $25 \mathrm{ppm}$ showed promising responses in terms of leaf enzyme activity as well as the total and reducing sugars in berries. Additionally, anthocyanin accumulation enhanced significantly when vines received the same treatment under a favorable temperature range. This work sheds light on the involvement of the antioxidant enzymes activity in improving table grape berry quality.

Supplementary Materials: The following materials are available online at https: / www.mdpi.com/ article/10.3390/plants10071285/s1, Figure S1: Daily minimum and maximum temperature (A \& B) between February to August during the two seasons 2019 and 2020 in the experimental site., Figure S2: Leaves Zinc content of Crimson seedless grapes following different treatments with $\mathrm{ZnO}$ and $\mathrm{ZnO}$ NPs. Different letters indicate differences based on Duncan's multiple range test.

Author Contributions: Conceptualization, M.K.A.E.-N., H.M.E.-H., M.S.F.S., T.A.S. and A.E.-K.; Data curation, M.K.A.E.-N. and M.S.F.S.; Formal analysis, M.K.A.E.-N.; Funding acquisition, H.M.E.H., T.A.S. and A.A.E.-Y.; Investigation, M.K.A.E.-N., H.M.E.-H., M.S.F.S. and T.A.S.; Methodology, M.K.A.E.-N., H.M.E.-H., M.S.F.S., T.A.S. and A.A.E.-Y.; Resources, H.M.E.-H., M.S.F.S., T.A.S., A.A.E.Y. and A.E.-K.; Software, M.K.A.E.-N. and M.S.F.S.; Supervision, H.M.E.-H., M.S.F.S. and T.A.S.; Validation, M.K.A.E.-N., H.M.E.-H., M.S.F.S. and T.A.S.; Writing-original draft, M.K.A.E.-N. and M.S.F.S.; Writing—review and editing, M.K.A.E.-N., H.M.E.-H., M.S.F.S., T.A.S., A.A.E.-Y. and A.E.-K. All authors have read and agreed to the published version of the manuscript. 
Funding: This research received no external funding.

Institutional Review Board Statement: Not applicable.

Data Availability Statement: All data are contained in this manuscript.

Conflicts of Interest: The authors declare that the research was conducted in the absence of any commercial or financial relationships that could be construed as a potential conflict of interest.

\section{References}

1. Baghdady, G.A.; Abdrabboh, G.A.; Shahda, M.A. Effect of Some Pre-Harvest Treatments on Yield and Fruit Quality of Crimson Seedless Grapevines. J. Biol. Chem. Environ. Sci. 2020, 15, 1-14.

2. El-Sayed, M.E.A. Improving Fruit Quality and Marketing of "Crimson Seedless" Grape Using Some Preharvest Treatments. J. Hort. Sci. Ornamen. Plants. 2013, 5, 218-226. [CrossRef]

3. Işçi, B.; Kacar, E.; Altındişli, A. The Effects of Some Exogenous Applications on Quality in 'Crimson Seedless' Grape. ErwerbsObstbau 2020, 62 (Suppl. 1), S87-S100. [CrossRef]

4. Dokoozlian, N.; Peacock, B.; Luvisi, D.; Vasquez, S. Cultural Practices for Crimson Seedless Table Grapes. Calif. Agricult. 1995, 49, 36-40. [CrossRef]

5. Yan, Y.; Song, C.; Falginella, L.; Castellarin, S.D. Day Temperature has a Stronger Effect than Night Temperature on Anthocyanin and Flavonol Accumulation in "Merlot" (Vitis vinifera L.) Grapes during Ripening. Front. Plant. Sci. 2020, 11, 1095. [CrossRef]

6. Karagiannis, E.; Tanou, G.; Samiotaki, M.; Michailidis, M.; Diamantidis, G.; Minas, I.S.; Molassiotis, A. Comparative physiological and proteomic analysis reveal distinct regulation of peach skin quality traits by altitude. Front. Plant. Sci. 2016, 7, 1-14. [CrossRef]

7. Karagiannis, E.; Michailidis, M.; Tanou, G.; Scossa, F.; Sarrou, E.; Stamatakis, G.; Samiotaki, M.; Martens, S.; Fernie, A.R.; Molassiotis, A. Decoding altitude-activated regulatory mechanisms occurring during apple peel ripening. Hortic. Res. 2020, 7 , 1-12. [CrossRef] [PubMed]

8. Mori, K.; Sugaya, S.; Gemma, H. Decreased anthocyanin biosynthesis in grape berries grown under elevated night temperature condition. Sci. Hort. 2005, 105, 319-330. [CrossRef]

9. Yahuaca, B.; Martinez-Peniche, R.; Reyes, J.L.; Madero, E. Effect of ethephon and girdling on berry firmness during storage of "Malaga Roja" grape. Acta Hort. 2006, 727, 459-465. [CrossRef]

10. Smart, R.E.; Smith, S.M.; Winchester, R.V. Light quality and quantity effects on fruit ripening for Cabernet Sauvignon. Am. J. Enol. Vitic. 1988, 39, 250-258.

11. Hunter, J.J.; De Villiers, O.T.; Watts, J.E. The effect of partial defoliation on quality characteristics of Vitis vinifera L. cv. Cabernet Sauvignon grapes. II. Skin color, skin sugar, and wine quality. Am. J. Enol. Vitic. 1991, 42, 13-18.

12. Medda, S.; Dessena, L.; Mulas, M. Monitoring of the PAL Enzymatic Activity and Polyphenolic Compounds in Leaves and Fruits of Two Myrtle Cultivars during Maturation. Agriculture 2020, 10, 389. [CrossRef]

13. El-Kereamy, A.; Chervin, C.; Roustan, J.-P.; Cheynier, V.; Souquet, J.-M.; Moutounet, M.; Raynal, J.; Ford, C.; Latché, A.; Pech, J.-C.; et al. Exogenous ethylene stimulates the long-term expression of genes related to anthocyanin biosynthesis in grape berries. Physiol. Plant. 2003, 119, 175-182. [CrossRef]

14. Kataoka, I.; Sugiura, A.; Utsunomiya, N.; Tomana, T. Effect of abscisic acid and defoliation on anthocyanin accumulation in Kyoho grapes (Vitis vinifera L. x V. labruscana Bailey). Vitis 1982, 21, 325-332. [CrossRef]

15. Samaan, M.S.F.; Nasser, M.A. Effect of spraying Paclobutrazol (PP333) on yield and fruit quality of Crimson seedless grape. J. Plant Prod. Mansoura Univ. 2020, 11, 1031-1034. [CrossRef]

16. Zhang, W.; Curtin, C.; Kikuchi, M.; Franco, C. Integration of jasmonic acid and light irradiation for enhancement of anthocyanin biosynthesis in Vitis vinifera suspension cultures. Plant. Sci. 2002, 162, 459-468. [CrossRef]

17. Wen, P.-F.; Chen, J.-Y.; Kong, W.-F.; Pan, Q.-H.; Wan, S.-B.; Huang, W.-D. Salicylic acid induced the expression of phenylalanine ammonia-lyase gene in grape berry. Plant. Sci. 2005, 169, 928-934. [CrossRef]

18. Ban, T.; Ishimaru, M.; Kobayashi, S.; Shiozaki, S.; Goto-Yamamoto, N.; Horiuchi, S. Abscisic acid and 2,4-dichlorophenoxyacetic acid affect the expression of anthocyanin biosynthetic pathway genes in 'Kyoho' grape berries. J. Hortic. Sci. Biotechnol. 2003, 78, 586-589. [CrossRef]

19. Jeong, S.T.; Goto-Yamamoto, N.; Kobayashi, S.; Esaka, M. Effects of plant hormones and shading on the accumulation of anthocyanins and the expression of anthocyanin biosynthetic genes in grape berry skins. Plant. Sci. 2004, 167, 247-252. [CrossRef]

20. González-SanJosé, M.L.; Diez, C. Relationship between anthocyanins and sugars during the ripening of grape berries. Food Chem. 1992, 43, 193-197. [CrossRef]

21. Song, C.-Z.; Liu, M.-Y.; Meng, J.-F.; Chi, M.; Xi, Z.-M.; Zhang, Z.-W. Promoting Effect of Foliage Sprayed Zinc Sulfate on Accumulation of Sugar and Phenolics in Berries of Vitis vinifera cv. Merlot Growing on Zinc Deficient Soil. Molecules 2015, 20, 2536-2554. [CrossRef] [PubMed]

22. Prasad, R.; Bhattacharyya, A.; Nguyen, Q.D. Nanotechnology in Sustainable Agriculture: Recent Developments, Challenges, and Perspectives. Front. Microbiol. 2017, 8, 1014. [CrossRef] [PubMed]

23. He, X.; Deng, H.; Hwang, H. The current application of nanotechnology in food and agriculture. J. Food Drug Anal. 2018, $27,1-21$. [CrossRef] [PubMed] 
24. Shang, Y.; Hasan, M.K.; Ahammed, G.J.; Li, M.; Yin, H.; Zhou, J. Applications of Nanotechnology in Plant Growth and Crop Protection: A Review. Molecules 2019, 24, 2558. [CrossRef]

25. War, J.M.; Fazili, M.A.; Mushtaq, W.; Wani, A.; Bhat, M.Y. Role of Nanotechnology in Crop Improvement. In Nanobiotechnology in Agriculture, Nanotechnology in the Life Sciences; Hakeem, K.R., Pirzadah, T.B., Eds.; Springer: Berlin/Heidelberg, Germany, 2020; pp. 63-97. [CrossRef]

26. Abdel Wahab, M.M.; Abdelaziz, S.M.; El-Mogy, M.M.; Abdeldaym, E.A. Effect of Foliar ZnO and FeO Nanoparticles Application on Growth and Nutritional Quality of Red Radish and Assessment of Their Accumulation on Human Health. Agriculture 2019, 65, 16-29. [CrossRef]

27. Prasad, T.; Sudhakar, P.; Sreenivasulu, Y.; Latha, P.; Munaswamy, V.; Reddy, K.; Sreeprasad, T.; Sajanlal, P.; Pradeep, T. Effect of nanoscale zinc oxide particles on the germination, growth and yield of peanut. J. Plant. Nutr. 2012, 35, 905-927. [CrossRef]

28. Tarafdar, J.; Raliya, R.; Mahawar, H.; Rathore, I. Development of zinc nanofertilizer to enhance crop production in pearl millet (Pennisetum americanum). Agri. Res. 2014, 3, 257-262. [CrossRef]

29. Venkatachalam, P.; Priyanka, N.; Manikandan, K.; Ganeshbabu, I.; Indiraarulselvi, P.; Geetha, N.; Muralikrishna, K.; Bhattacharya, R.C.; Tiwari, M.; Sharma, N.; et al. Enhanced plant growth promoting role of phycomolecules coated zinc oxide nanoparticles with P supplementation in cotton (Gossypium hirsutum L.). Plant. Physiol Biochem. 2017, 110, 118-127. [CrossRef]

30. Iziy, E.; Majd, A.; Vaezi-Kakhki, M.R.; Nejadsattari, T.; Noureini, S.K. Effects of zinc oxide nanoparticles on enzymatic and nonenzymatic antioxidant content, germination, and biochemical and ultrastructural cell characteristics of Portulaca oleracea L. Acta Soc. Bot. Pol. 2019, 88, 3639. [CrossRef]

31. Rossi, L.; Fedenia, L.N.; Sharifan, H.; Ma, X.; Lombardini, L. Effects of foliar application of zinc sulfate and zinc nanoparticles in coffee (Coffea arabica L.) plants. Plant. Physiol. Biochem. 2019, 135, 160-166. [CrossRef]

32. Narendhran, S.; Rajiv, P.; Sivaraj, R. Influence of zinc oxide nanoparticles on growth of Sesamum indicum L. in zinc deficient soil. Int. J. Pharm. Sci. 2016, 3, 365-371.

33. García-López, J.I.; Niño-Medina, G.; Olivares-Sáenz, E.; Lira-Saldivar, R.H.; Barriga-Castro, E.D.; Vázquez-Alvarado, R.; Rodríguez-Salinas, P.A.; Zavala-García, F. Foliar Application of Zinc Oxide Nanoparticles and Zinc Sulfate Boosts the Content of Bioactive Compounds in Habanero Peppers. Plants 2019, 8, 254. [CrossRef]

34. Alharby, H.F.; Metwali, E.M.R.; Fuller, M.P.; Aldhebiani, A.Y. Impact of application of zinc oxide nanoparticles on callus induction, plant regeneration, element content and antioxidant enzyme activity in tomato (Solanum lycopersicum Mill.) under salt stress. Arch. Biol. Sci. 2016, 68, 723-735. [CrossRef]

35. Ahmad, P.; Alyemeni, M.N.; Al-Huqail, A.A.; Alqahtani, M.A.; Wijaya, L.; Ashraf, M.; Kaya, C.; Bajguz, A. Zinc Oxide Nanoparticles Application Alleviates Arsenic (As) Toxicity in Soybean Plants by Restricting the Uptake of as and Modulating Key Biochemical Attributes, Antioxidant Enzymes, Ascorbate-Glutathione Cycle and Glyoxalase System. Plants 2020, 9, 825. [CrossRef]

36. Karimzadeh, F.; Haddad, R.; Garoosi, G.; Khademian, R. Effects of Nanoparticles on Activity of Lignan Biosynthesis Enzymes in Cell Suspension Culture of Linum usitatissimum L. Russ. J. Plant. Physiol. 2019, 66, 756-762. [CrossRef]

37. Farghaly, F.A.; Radi, A.A.; Al-Kahtany, F.A.; Hamada, A.M. Impacts of zinc oxide nano and bulk particles on redox-enzymes of the Punica granatum callus. Sci. Rep. 2020, 10, 1922. [CrossRef]

38. Fawzi, A.F.A.; Elfouly, M.M.; Moubarak, Z.M. The Need of Grain Legumes for Iron, Manganese, and Zinc Fertilization under Egyptian Soil-Conditions-Effect and Uptake of Metalosates. J. Plant. Nutr. 1993, 16, 813-823. [CrossRef]

39. Pandey, N.; Gupta, B.; Pathak, G.C. Enhanced yield and nutritional enrichment of seeds of Pisum sativum L. through foliar application of zinc. Sci. Hortic. 2013, 164, 474-483. [CrossRef]

40. Saadati, S.; Moallemi, N.; Mortazavi, S.M.H.; Seyyednejad, S.M. Effects of zinc and boron foliar application on soluble carbohydrate and oil contents of three olive cultivars during fruit ripening. Sci. Hortic. 2013, 164, 30-34. [CrossRef]

41. Zhang, Y.; Hu, C.-X.; Tan, Q.-L.; Zheng, C.-S.; Gui, H.-P.; Zeng, W.-N.; Sun, X.-C.; Zhao, X.-H. Plant nutrition status yield and quality of satsuma mandarin (Citrus unshiu Marc.) under soil application of Fe-EDDHA and combination with zinc and manganese in calcareous soil. Sci. Hortic. 2014, 174, 46-53. [CrossRef]

42. Song, C.-Z.; Liu, M.-Y.; Men, J.-F.; Shi, P.-B.; Zhang, Z.-W.; Xi, Z.-M. Influence of foliage-sprayed zinc sulfate on grape quality and wine aroma characteristics of Merlot. Eur. Food Res. Technol. 2015, 242, 609-623. [CrossRef]

43. Davarpanah, S.; Tehranifar, A.; Davarynejad, G.; Abadía, J.; Khorasani, R. Effects of foliar applications of zinc and boron nano-fertilizers on pomegranate (Punica granatum cv. Ardestani) fruit yield and quality. Sci. Hortic. 2016, 210, 57-64. [CrossRef]

44. Usha, K.; Singh, B. Effects of macro and micro nutrient spray on fruit yield and quality of grapes (Visit vinifera L.) cv. Perlette. Acta. Hort. 2002, 594, 197-202. [CrossRef]

45. Abou-Zaid, E.A.A.; Shaaban, M.M. Growth, yield and berries quality in Red Roomy grapevines improved under different foliar application of Spirulina algae, zinc and boron. Mid. East J. Agri. Res. 2019, 8, 654-661.

46. Hu, C.; Liu, Y.; Li, X.; Li, M. Biochemical responses of duckweed (Spirodela polyrhiza) to zinc oxide nanoparticles. Arch. Environ. Cont. Toxicol. 2013, 64, 643-651. [CrossRef] [PubMed]

47. Faizan, M.; Faraz, A.; Yusuf, M.; Khan, S.T.; Hayat, S. Zinc oxide nanoparticle-mediated changes in photosynthetic efficiency and antioxidant system of tomato plants. Photosynthetica 2018, 56, 678-686. [CrossRef]

48. Faizan, M.; Faraz, A.; Hayat, S. Effective use of zinc oxide nanoparticles through root dipping on the performance of growth, quality, photosynthesis and antioxidant system in tomato. J. Plant. Bioch. Biotech. 2020, 29, 553-567. [CrossRef] 
49. Kouhi, S.M.M.; Lahouti, M.; Ganjeali, A.; Entezari, M.H. Comparative Phytotoxicity of ZnO Nanoparticles, ZnO Microparticles, and $\mathrm{Zn}^{2+}$ on Rapeseed (Brassica napus L.): Investigating a wide Range of Concentrations. Toxicol. Environ. Chem. 2015, 96, 861-868. [CrossRef]

50. Thomas, B.F.; ElSohly, M.A. Biosynthesis and Pharmacology of Phytocannabinoids and Related Chemical Constituents. Anal. Chem. Cannabis. 2016, 27-41. [CrossRef]

51. Wadhwa, N.; Joshi, U.N.; Mehta, N. Zinc Induced Enzymatic Defense Mechanisms in Rhizoctonia Root Rot Infected Cluster Bean Seedlings. J. Bot. 2014, 1-7. [CrossRef]

52. Mori, K.; Goto-Yamamoto, N.; Kitayama, M.; Hashizume, K. Loss of anthocyanins in red-wine grape under high temperature. J. Exp. Bot. 2007, 58, 1935-1945. [CrossRef]

53. Cohen, S.D.; Tarara, J.M.; Kennedy, J.A. Assessing the impact of temperature on grape phenolic metabolism. Anal. Chim. Acta 2008, 621, 57-67. [CrossRef] [PubMed]

54. Ortega-Regules, A.; Romero-Cascales, I.; López-Roca, J.M.; Ros-García, J.M.; Gómez-Plaza, E. Anthocyanin fingerprint of grapes: Environmental and genetic variations. J. Sci. Food Agr. 2006, 86, 1460-1467. [CrossRef]

55. Biswas, T.; Mathur, A. Plant Anthocyanins: Biosynthesis, Bioactivity and in vitro Production from tissue cultures. Adv. Biotech. Micro. 2017, 5, 555672. [CrossRef]

56. Hashemi, S.; Asrar, Z.; Pourseyedi, S.; Nadernejad, N. Investigation of ZnO Nanoparticles on Proline, Anthocyanin Contents and Photosynthetic Pigments and Lipid Peroxidation in the Soybean. IET Nanobiotechnol. 2018, 13, 66-70. [CrossRef] [PubMed]

57. Raigond, P.; Raigond, B.; Kaundal, B.; Singh, B.; Joshi, A.; Dutt, S. Effect of Zinc Nanoparticles on Antioxidative System of Potato Plants. J. Environ. Biol. 2017, 38, 435-439. [CrossRef]

58. Oloumi, H.; Soltaninejad, R.; Baghizadeh, A. The comparative Effects of Nano and Bulk Size Particles of CuO and ZnO on Glycyrrhiza glabra L. Seedlings. Ind. J. Plant. Physiol. 2015, 20, 157-161. [CrossRef]

59. Suganya, A.; Saravanan, A.; Manivannan, N. Role of Zinc Nutrition for Increasing Zinc Availability, Uptake, Yield and Quality of Maize (Zea Mays L.) Grains: An Overview. Comm. Soil Sci. Plant. Anal. 2020, 51, 2001-2021. [CrossRef]

60. Long, L.; Chen, J.; Zhang, Y.; Liang, X.; Ni, H.; Zhang, B.; Yin, Y. Comparison of porous and nano zinc oxide for replacing high-dose dietary regular zinc oxide in weaning piglets. PLOS ONE 2017, 12, e0182550. [CrossRef]

61. Washington, I.M.; Van Hoosier, G. Clinical Biochemistry and Hematology. In The Laboratory Rabbit, Guinea Pig, Hamster, and Other Rodents; Academic Press: Cambridge, MA, USA, 2012; pp. 57-116. [CrossRef]

62. Bashandy, S.A.E.; Alaamer, A.; Moussa, S.A.A.; Omara, E.A. Role of zinc oxide nanoparticles in alleviating hepatic fibrosis and nephrotoxicity induced by thioacetamide in rats. Canadian J. Physi. Pharma. 2018, 96, 337-344. [CrossRef]

63. Sidra, S.; Arshad, M.; Chaudhari, S.K. Zinc Oxide Nanoparticles for Revolutionizing Agriculture: Synthesis and Applications. Sci. World J. 2014, 2014, 1-8. [CrossRef]

64. Hassan, N.S.; Salah El Din, T.A.; Hendawey, M.H.; Borai, I.H.; Mahdi, A.A. Magnetite and zinc oxide nanoparticles alleviated heat stress in wheat plants. Curr. Nanomater. 2018, 3, 32-43. [CrossRef]

65. Wolf, T.K. Effects of rootstock and nitrogen fertilization on the growth yield of grapevines in New York. Am. J. Enol. Vitic. 1988, 39, 29-33.

66. Carter, G.A. Responses of leaf spectral reflectance to plant stress. Am. J. Bot. 1993, 80, 239-243. [CrossRef]

67. AOAC-Association of Official Analytical Chemists International. Official Methods of Analysis, 16th ed.; AOAC: Arlington, VA, USA, 1995.

68. Şirin, S.; Aydaş, S.B.; Aslim, B. Biochemical Evaluation of Phenylalanine Ammonia Lyase (PAL) from Endemic Cyathobasis fruticulosa (Bunge) Aellen for the Dietary Treatment of Phenylketonuria (PKU). Food Technol. Biotechnol. 2016, 54, 296-313. [CrossRef]

69. Beyer, W.F.; Fridovich, I. Assaying for superoxide dismutase activity: Some large consequences of minor changes in condition. Anal. Biochem. 1987, 161, 559-566. [CrossRef]

70. Connor, A.M.; Luby, J.J.; Finn, C.E.; Hancock, J.F. Genotypic and environmental variation in antioxidant activity among blueberry cultivars. Acta Hortic. 2002, 574, 209-213. [CrossRef]

71. Lima, A.B.; Corrêa, A.D.; Saczk, A.A.; Martins, M.P.; Castilho, R.O. Anthocyanins, pigment stability and antioxidant activity in jabuticaba [Myrciaria cauliflora (Mart.) O. Berg]. Rev. Bras. Frutic. 2011, 33, 877-887. [CrossRef]

72. Shaffer, P.A.; Hartmann, A.F. The Iodometric Determination of Copper and Its Use in Sugar Analysis. J. Biol. Chem. 1921, 45, 349-364. [CrossRef]

73. Duncan, D.B. Multiple range and multiple F tests. Biometrics 1955, 11, 1-42. [CrossRef] 